\title{
Review of Scopoletin: Isolation, Analysis Process, and Pharmacological Activity
}

\author{
Adang Firmansyah ${ }^{1}$ (D), Wiwin Winingsih ${ }^{1}$ (D) , Jesicha Dian Yenbyeebe Manobi ${ }^{1, *}$ (D) \\ 1 Sekolah Tinggi Farmasi Indonesia ,Bandung, West Java, Indonesia \\ * Correspondence: adangfirmansyah@stfi.ac.id;
}

Received: 17.10.2020; Revised: 22.12.2020; Accepted: 23.12.2020; Published: 29.12.2020

\begin{abstract}
Scopoletin (7-hydroxy-6-methoxy coumarin) is a coumarin phenolic compound widely found in plants and includes coumarin derivatives that are superior in several types of plants. This article was created to provide information regarding the isolation process, analysis, and pharmacological activity. The method used is to study and analyze scopoletin articles from national and international journals. From the data sources studied, the yield of scopoletin extract in Morinda citrifolia L was $0.93 \%$, Helichrysum italicum was $1.933 \mathrm{mg} / 100 \mathrm{~g}$. The scopoletin content in Convolvulus pluricaulis is $0.1738 \%$, Artemisia апnиa is $0.3 \%$, Lasianthus lucidus is $54 \mathrm{mg}$, and Morus alba L. (Po-sa) is $0.0009 \%$. The highest yield of scopoletin extract was $0.93 \%$ found in noni (Morinda citrifolia L) using the Soxhlet method. The highest scopoletin content was $0.3 \%$ in Artemisia annua using column chromatography and recrystallization. Scopoletin identification can be done using Thin Layer Chromatography (TLC), High-Performance Liquid Chromatography (HPLC), Fourier Transform Infrared Spectrophotometer (FTIR), Nuclear Magnetic Resonance, and Mass Spectrometry. Based on in vitro studies, scopoletin has pharmacological activities, including as an antihepatotoxicity, antibacterial, antifungal, antitubercular, and antioxidant. Pharmacological activities that have been proven in vivo are antithyroid, antihypertensive, anti-proliferative, anti-inflammatory, neurological, anti-dopaminergic and anti-adrenergic, antidiabetic, and antihyperuricemic activities. From the various pharmacological activities of scopoletin, it has the potential to be further developed.
\end{abstract}

Keywords: scopoletin; isolation; analysis; pharmacological activity.

(C) 2020 by the authors. This article is an open-access article distributed under the terms and conditions of the Creative Commons Attribution (CC BY) license (https://creativecommons.org/licenses/by/4.0/).

\section{Introduction}

Scopoletin is phenolic coumarin derived from the phenylpropanoid pathway and can be isolated from various plants [1,2]. The presence of scopoletin was initially detected by thinlayer chromatography (TLC). Its various pharmacological activities have been further described in several studies [3]. Further identification or isolation of scopoletin using several methods, namely the Soxhlet method, reflux, percolation, maceration, and supercritical $\mathrm{CO}_{2}$ and can be analyzed using Mass spectrometry, high-performance liquid chromatography (HPLC), Nuclear Magnetic Resonance, and Fourier-transform infrared spectroscopy (FTIR).

From the background presented, this article was intended to provide a collection of information about a more efficient way to isolate, analyze, and determine the compound scopoletin's pharmacological activity. 


\section{Source of Scopoletin}

Scopoletin is very common in the plant kingdom and can be isolated from various parts of the plant (roots, fruits, leaves, stems, etc.) [1], such as Sinomonium acutum [4], Solanum lyratum [5], roots of Brunfelsia hopeana [6], Artemisia feddei [7], Helichrysum italicum [8], Manihot esculenta [9], Canscora decussate [10], Chenopodium murale [11], Erycibe obtusifolia Benth [12], Hypochaeris radicata [13], Cirsium setidens [14], Aleurites moluccana (L.) [15], Lasianthus lucidus Blume [16], Morinda citrifolia [17], Nicotiana tabacum [18], Ipomoea digitata [19], Aegle marmelos [20], Ipomoea reniformis [21], Artemisia iwayomogi [22], Macaranga gigantifolia Merr [23], Artemisia annua [24], Tetrapleura tetraptera [25], Tilia cordata Mill. [26], Melia azedarach L. [27] Acer saccharum Marsh. [28], Hymenodictyon obovatum [29], Fagraea ceilanica [30], Magnolia fargesii [31], Morus alba L. (Po-sa) [32], Clausena excavate Burm.f. (Pyin-daw-thein) [33].

\section{Pharmacological Activity Of Scopoletin}

Scopoletin has several pharmacological activities, namely antihepatotoxicity [5], antibacterial [16], antithyroid [20], antifungal [27,34,35], antitubercular [36], antimigratory [37], antihypertensive [38,39], antioxidant [40], antiproliferative [41], antiinflamation [17,4247], neurological [48-53], antidopaminergic and antiadrenergic [54], Antidiabetic [55], Antihyperuricemic [56]. Pharmacological activities of Scopoletin were tabulated in table 1.

Table 1. Pharmacological Activity Of Scopoletin.

\begin{tabular}{|c|c|c|}
\hline Pharmacologycal act & Dose & Reference \\
\hline Antihepatotoxicity & $\begin{array}{l}\text { Scopoletin can significantly reduce the release of glutamate pyruvate } \\
\text { transaminase and sorbitol dehydrogenase by } 53 \% \text { and } 58 \% \text { in the } \\
\text { initial carbon tetrachloride poisoning rat liver cells at doses of } 1 \text { to } \\
50 \mathrm{M} \text {. }\end{array}$ & {$[5]$} \\
\hline Antibacterial & $\begin{array}{l}\text { scopoletin } 1,4 \mu \mathrm{mol} / \mathrm{g} \text { in bark ( } 200 \mathrm{~g} \text { dry weight) showed activity } \\
\text { as an anti-pseudomonas preparation. }\end{array}$ & {$[16]$} \\
\hline Antithyroid & $\begin{array}{l}\text { Taking Scopoletin }(1.00 \mathrm{mg} / \mathrm{kg} \text {, p.o.) daily for } 7 \text { consecutive days } \\
\text { can reduce serum thyroid hormone levels and glucose } 6 \text { phosphatase } \\
\text { and sugar activity. }\end{array}$ & {$[20]$} \\
\hline \multirow{3}{*}{ Antifungal } & $\begin{array}{l}\text { Scopoletin has excellent inhibitory activity on ordering AGEs, with } \\
\text { an IC50 value of } 2.93 \mu \mathrm{M} \text { and an RLAR inhibitory activity with an } \\
\text { IC50 value of } 22.5 \mu \mathrm{M} \text {. }\end{array}$ & [27] \\
\hline & $\begin{array}{l}\text { The minimum concentration inhibitory ranges were } 0.07 \pm 0.00 \mu \mathrm{g} / \\
\mathrm{ml} \text { and } 0.15 \pm 0.00 \mu \mathrm{g} / \mathrm{ml} \text {. The antifungal activity of scopoletin can } \\
\text { extract some destructive fungi in food. }\end{array}$ & [34] \\
\hline & $\begin{array}{l}\text { The minimum inhibitory concentration (MIC90) of scopoletin } \\
\text { against Candida was } 67.22 \text {, and } 119 \mu \mathrm{g} / \mathrm{mL} \text { was effective against } \\
\text { Candida. And antifungal activity. }\end{array}$ & [35] \\
\hline Antitubercular & $\begin{array}{l}\text { Scopoletin at a dose of } 40 \mathrm{mg} / \mathrm{ml} \text { can be used as an anti-tuberculosis } \\
\text { drug for Mycobacterium tuberculosis strain H37Rv. }\end{array}$ & [36] \\
\hline Antimigratory & $\begin{array}{l}\text { Scopoletin } 0.58 \%(\mathrm{w} / \mathrm{w}) \text { and can inhibit viability, move to MCF-7 } \\
\text { cells, and can be developed as an anticancer drug for breast cancer. }\end{array}$ & {$[37]$} \\
\hline \multirow{2}{*}{ Antihypertensive } & $\begin{array}{l}\text { Scopoletin } 0.46+0.05 \% \text { can significantly reduce blood pressure in } \\
\text { hypertensive rats. }\end{array}$ & {$[38]$} \\
\hline & $\begin{array}{l}\text { Scopoletin at doses of } 1,3 \text {, and } 10 \mathrm{mg} / \mathrm{kg} \text { decreased IL-4 type I } \\
\text { levels, and Scopoletin at doses of } 10 \mathrm{mg} / \mathrm{kg} \text { decreased serum levels. }\end{array}$ & {$[39]$} \\
\hline Antioxidant & Scopoletin $(17.4 \mu \mathrm{g} / \mathrm{mL})$ showed potential antioxidant activity. & {$[40]$} \\
\hline Anti-proliferative & $\begin{array}{l}\text { The anti-proliferative effect of scopoletin on all cancer cell lines } \\
\text { (IC50 } 103 \text { and above } 600 \mu \mathrm{g} / \mathrm{ml} \text { ) was reduced. }\end{array}$ & {$[41]$} \\
\hline \multirow[t]{2}{*}{ Antiinflammation } & $\begin{array}{l}\text { Scopoletin } 0.62 \mu \mathrm{mol} / \mathrm{g} \text { inhibited nitric oxide (NO) production in a } \\
\text { manner dependent on lipopolysaccharide-induced RAW } 264.7 \\
\text { (LPS) macrophage cell concentration. It was shown that quinones } \\
\text { were induced in } 1 \mathrm{c} 1 \mathrm{c} 7 \text { Reductase (QR) hepatocyte culture. }\end{array}$ & [17] \\
\hline & $\begin{array}{l}\text { Scopoletin } 100 \mathrm{mg} / \mathrm{kg} \text { showed anti-inflammatory activity in rat ear } \\
\text { edema caused by croton oil. }\end{array}$ & [42] \\
\hline
\end{tabular}




\begin{tabular}{|c|c|c|}
\hline Pharmacologycal act & Dose & Reference \\
\hline & $\begin{array}{l}\text { Scopoletin }(0.63-2.50 \mathrm{~g} / \mathrm{kg}) \text { is a potential preventive and therapeutic } \\
\text { agent for inflammatory gastroesophageal diseases, mainly through } \\
\text { its antisecretory and promoter activities, including serotonin } \\
\text { inhibition, free radicals, and inflammation-mediated cytokine } \\
\text { effects. }\end{array}$ & {$[43]$} \\
\hline & $\begin{array}{l}\text { Scopoletin showed significant activity on LDL oxidation }(\text { IC50 = } \\
10.2 \mu \mathrm{M}) \text {, and exerted a vascular anti-inflammatory effect on human } \\
\text { endothelial cells EA.hy } 926 \text { activated by TNF- } \alpha \text {. }\end{array}$ & [44] \\
\hline & $\begin{array}{l}\text { Scopoletin }(2.0,10.0,50.0 \mathrm{mg} / \mathrm{kg}) \text { demonstrated that inhibition of } \\
\text { nuclear factor- } \mathrm{kB} \text { and mitogen-activated protein kinase signaling } \\
\text { pathways involved in anti-inflammatory activity and regulation of } \\
\text { the excitatory/inhibitory balance may be associated with anxiolytic } \\
\text { effects. }\end{array}$ & [45] \\
\hline & $\begin{array}{l}\text { It has an inhibitory effect on HNE (human neutrophil elastase) } \\
\text { activity, with IC50 values ranging from } 3.6 \text { to } 74.3 \mu \mathrm{M} \text {. }\end{array}$ & {$[46]$} \\
\hline & $\begin{array}{l}\text { Scopoletin can prevent oxidative stress and apoptosis, as well as } \\
\text { activate Nrf } 2 \text { signaling. }\end{array}$ & [47] \\
\hline \multirow{6}{*}{ Neurological } & $\begin{array}{l}\text { Scopoletin }(10 \mathrm{mg} / \mathrm{kg} \text {, po) exhibits effects such as antidepressant } \\
\text { depending on serotonergic drugs (5-HT2A receptors), noradrenergic } \\
\text { systems ( } \alpha 1-\text { and } \alpha 2 \text {-adrenergic receptors), and dopaminergic drugs } \\
\text { (dopamine D1 and D2 receptors). }\end{array}$ & [48] \\
\hline & $\begin{array}{l}\text { Scopoletin, which is confirmed to be the main component of the } \\
\text { extract, is a GABA-T inhibitor (IC50 = } 10.57 \mathrm{M} \text { ). }\end{array}$ & [49] \\
\hline & $\begin{array}{l}\text { The decrease in Bid, Bax, and caspase- } 9 \text { expression induced by } \\
\text { scopoletin will decrease cleaved caspase- } 3 \text { expression, inhibit } \\
\text { cleaved PARP expression, and ultimately inhibit the mitochondrial } \\
\text { apoptotic pathway. }\end{array}$ & [50] \\
\hline & $\begin{array}{l}\text { Scopoletin } 100 \mathrm{mg} / \mathrm{kg} \text { indicates that Scopoletin provides } \\
\text { neuroprotection, reduces neuronal apoptosis, and improves neuronal } \\
\text { autophagy. }\end{array}$ & {$[51]$} \\
\hline & $\begin{array}{l}\text { The IC50 concentrations of scopoletin that inhibited the AChE and } \\
\text { BuChE enzymes were } 5.34 \text { and } 9.11 \mu \mathrm{M} \text {, respectively. }\end{array}$ & {$[52]$} \\
\hline & $\begin{array}{l}\text { Initial treatment of SH-SY5Y cells with } 5 \mathrm{mM} \text { scopoletin can } \\
\text { prevent } \mathrm{H}_{2} \mathrm{O}_{2} \text { induced cell death and reduce levels of apoptotic cells } \\
\text { and ROS. }\end{array}$ & [53] \\
\hline $\begin{array}{l}\text { Antidopaminergic and } \\
\text { Antiadrenergic }\end{array}$ & $\begin{array}{l}\text { The baseline dose for Eastern mice }(<200 \mu \mathrm{g} / \mathrm{ml}) \text { showed anti- } \\
\text { dopaminergic and anti-adrenergic activity in mice. }\end{array}$ & {$[54]$} \\
\hline Antidiabetic & $\begin{array}{l}\text { Scopoletin has a diabetes-stimulating effect, can stimulate GLUT4 } \\
\text { transport, and regulate glucose uptake via plasma membrane } \\
\text { activation of PI3K and AMPK pathways in 3T3-L1 adipocytes. }\end{array}$ & [55] \\
\hline Antihyperuricemic & $\begin{array}{l}\text { After continuous oral administration, Scopoletin exhibits a weak } \\
\text { urate reduction effect. Sphingolipids have an inhibitory effect on } \\
\text { XOD activity in serum and liver. }\end{array}$ & {$[56]$} \\
\hline
\end{tabular}

\section{Physicochemical Properties Of Scopoletin}

Scopoletin is also known as the pigment 7-hydroxy-6-methoxychromen-2-one (Figure 1), is a simple coumarin group derived from 1,2-benzopyrones found in higher plants, synthesized from a common phenylpropanoid pathway [3]. Scopoletin has several synonyms: Gelseminic acid, Chrysatropic acid, Scopoletine, 6-Methylesculetin, Murrayetin, and Scopoletol, Escopoletin, Methylesculetin, 6-O-Methylesculetin, Esculetin-6-methyl ether, 7Hydroxy-5-methoxycoumarin, 6-Methoxyumbelliferone [44]. Research conducted [21] states that scopoletin has a melting point of $202-204^{\circ} \mathrm{C}$, has the chemical formula $\mathrm{C}_{10} \mathrm{H}_{8} \mathrm{O}_{4}$ with a molecular weight of $192.17 \mathrm{~g} / \mathrm{mol}$, boiling point: $413.5^{\circ} \mathrm{C}$, and flash point: $172.4^{\circ} \mathrm{C}$, scopoletin light-yellow amorphous powder [57]. Scopoletin's solubility study found that it can be miscible in organic solvents such as ethanol, Dimethyl sulfoxide (DMSO), and dimethylformamide (DMF), which must be cleaned with an inert gas. The solubility of scopoletin in this solvent was about 2, 30, and $50 \mathrm{mg} / \mathrm{ml}$, respectively [58]. Scopoletin is soluble in acetonitrile [1], methanol, ethyl acetate, and N-hexane [59]. Scopoletin is slightly soluble in water and slightly soluble in aqueous buffers. DMF should be added to the scopoletin 
aqueous solution to enhance its solubility in the buffered solution. Scopoletin has a solubility of about $0.2 \mathrm{mg} / \mathrm{ml}$ in DMF: PBS (pH 7.2) 1: 4 [58].<smiles>COc1cc2ccc(=O)oc2cc1O</smiles>

Figure 1. Chemical Structure of Scopoletin.

\section{Isolation and Analysis Of Scopoletin}

Scopoletin compounds can be obtained by the isolation method. A system, a traditional separation procedure for the continuous extraction of fresh or dry plant material with increasing polarity solvents. For this, the solvents methanol, acetonitrile, ethanol, hexane are usually used. This is because these compounds are relatively easy to dissolve in these compounds. Recently, many studies have used methanol [16,61], aqueous acetonitrile (1: $5 \mathrm{v} / \mathrm{v})$ [1] or various types of solvents (hexane, ethanol and methanol) [62]. A detailed description of the multistep method for extraction and purification of scopoletin has recently been presented from several plants (Table 2), including the stem of Artemisia annua [1], Helichrysum italicum [8], Lasianthus lucidus Blume [16], Morus alba L. (Po-sa) [32], Morinda citrifolia L [62], Convolvulus pluricaulis [81].

Tabel 2. The isolation process of Scopoletin.

\begin{tabular}{|c|c|c|c|}
\hline Isolation method & Solvent & $\%$ Yield & Reference \\
\hline $\begin{array}{l}\text { Percolation for } 6-8 \text { hours. Column } \\
\text { Chromatography. Elution of scopoletin in a } \\
\text { methanol chloroform mixture. }\end{array}$ & $\begin{array}{l}\text { (acetonitrile: water) dilute } \\
\text { acetonitrite in the ratio } 1: 5\end{array}$ & $0,3 \%$ & [1] \\
\hline $\begin{array}{l}\text { Supercritical fluid extraction (SFE). Dried } \\
\text { immortelle flowers were weighed at } 1.5 \\
\mathrm{MPa} \text { and } 25^{\circ} \mathrm{C} . \mathrm{CO}_{2} \text { flow rate }(1.94 \mathrm{~kg} / \mathrm{hr}) \text {. } \\
\text { Each extraction process lasts for } 90 \mathrm{~min} \text {. } \\
\text { The extract was stored at } 4-6^{\circ} \mathrm{C} \text { until } \\
\text { HPLC analysis. }\end{array}$ & $\mathrm{CO}_{2}$ & $\begin{array}{l}1.933 \mathrm{mg} / 100 \mathrm{~g} \text { from } \\
\text { the H. italicum flower }\end{array}$ & [8] \\
\hline $\begin{array}{l}\text { Maceration. The extract MeOH was applied } \\
\text { to a glass column filled with } 25 \text { to } 40 \mu \mathrm{m} \\
\text { silica gel. The fraction was checked for } \\
\text { purity by thin-layer chromatography (TLC) } \\
\text { and UV detection (wavelength } 365 \mathrm{~nm} \text { ). }\end{array}$ & Methanol & $54 \mathrm{mg}$ & [16] \\
\hline $\begin{array}{l}\text { Pet-Ether is obtained and defatted, then } \\
\text { divided into ethyl acetate and water. The } \\
\text { ethyl acetate soluble extract was obtained, } \\
\text { separated by gradient elution column } \\
\text { chromatography. From this separation, F2 is } \\
\text { collected. From the condensed fraction F2, } \\
\text { the scopoletin compound was collected by } \\
\text { paper chromatography with a solvent } \\
\text { formate } / \mathrm{A}: \mathrm{H}_{2} \mathrm{O}(2: 98) \text {. }\end{array}$ & $\begin{array}{l}\text { The } 95 \% \text { ethanol extract was } \\
\text { extracted with pet-ether }\left(60 \mathrm{C}-80^{\circ}\right. \\
\text { C). }\end{array}$ & $0,0009 \%$ & {$[32]$} \\
\hline $\begin{array}{l}\text { Soxhlet. The extract was examined by gas } \\
\text { chromatography-mass spectrometry (GC- } \\
\text { MS) technique. }\end{array}$ & $\begin{array}{l}\text { various types of solvents (hexane, } \\
\text { ethanol, and methanol) at } 90^{\circ} \mathrm{C} \\
\text { for ethanol, } 75^{\circ} \mathrm{C} \text { for methanol } \\
\text { and hexane, for } 4 \text { hours. }\end{array}$ & $0.93 \%$ & [62] \\
\hline $\begin{array}{l}\text { Extract at reflux } 80-85 \mathrm{C} \text { for } 1-2 \text { hours. The } \\
\text { extract was examined with HPLC. }\end{array}$ & $\begin{array}{l}\text { Methanol }(99 \%), 50 \% \text { alcohol, } \\
\text { and water. }\end{array}$ & $0,1738 \%$ & [81] \\
\hline
\end{tabular}

Scopoletin has been observed for decades. Identification and quantification are carried out in a variety of ways, including thin-layer chromatography (TLC), high-performance liquid chromatography (HPLC), and gas chromatography-mass spectrometry (GC-MS) [3]. The most 
common method used to filter fractions from the separation process is thin layer chromatography (Table 3) $[10,16,21,27,28,30,33,63,64,65]$. When a thin layer chromatography (TLC) plate was developed under ultraviolet irradiation with a wavelength of $365 \mathrm{~nm}$, Scopoletin emitted blue fluorescence [66].

Table 3. Identification method of Scopoletin identification by TLC.

\begin{tabular}{|c|c|c|c|}
\hline Mobile Phase & Stationary Phase & Retention Factor (Rf) & Reference \\
\hline $\begin{array}{l}\mathrm{C}_{4} \mathrm{H}_{8} \mathrm{O}_{2}: \mathrm{CH}_{3} \mathrm{COOH}: \mathrm{CH}_{2} \mathrm{O}_{2}: \mathrm{H}_{2} \mathrm{O} \\
(10: 0,5: 0,5: 1,5)\end{array}$ & $\begin{array}{c}\text { Silica Gel 60F } 254 \text { (Merck, } \\
\text { Darmstadt, Germany) }\end{array}$ & 0,78 & {$[10]$} \\
\hline $\begin{array}{l}\mathrm{C}_{6} \mathrm{H}_{14}: \mathrm{C}_{4} \mathrm{H}_{8} \mathrm{O}_{2} \\
(7: 3)\end{array}$ & $\begin{array}{c}\text { Silica Gel } 60 \mathrm{~F}_{254}(20 \times 20 \\
\mathrm{cm} ; \text { Merck })\end{array}$ & 0,5 & {$[16]$} \\
\hline $\begin{array}{l}\mathrm{C}_{7} \mathrm{H}_{8}: \mathrm{C}_{4} \mathrm{H}_{8} \mathrm{O}_{2}: \mathrm{CH}_{2} \mathrm{O}_{2} \\
(5: 4: 1)\end{array}$ & Silica Gel G as adsorbant & 0,47 & {$[21]$} \\
\hline $\begin{array}{l}\mathrm{CHCl}_{3}: \mathrm{C}_{2} \mathrm{H}_{3} \mathrm{~N} \\
(2: 1)\end{array}$ & $\begin{array}{l}\text { Silica Gel 60F } 254 \text { (Merck, } \\
\text { Darmstadt, Germany) }\end{array}$ & 0,75 & {$[27]$} \\
\hline $\begin{array}{l}\mathrm{C}_{6} \mathrm{H}_{6}: \mathrm{C}_{2} \mathrm{H}_{5} \mathrm{OH} \\
(100: 22)\end{array}$ & $\begin{array}{l}\text { Silica Gel impregnated with } \\
\text { a fluorescent dye. }\end{array}$ & 0.42 & {$[28]$} \\
\hline $\begin{array}{l}\mathrm{C}_{6} \mathrm{H}_{14}: \mathrm{C}_{4} \mathrm{H}_{8} \mathrm{O}_{2} \\
(7: 3)\end{array}$ & Silica Gel $60 \mathrm{~F}_{254}$ & 0,42 & {$[30]$} \\
\hline PE: EtOAc (1: 2) & $\begin{array}{c}\text { Silica Gel }(40-60 \mu \mathrm{m}, \\
\text { Wakogel })\end{array}$ & 0,5 & [33] \\
\hline $\begin{array}{l}\mathrm{CH}_{2} \mathrm{Cl}_{2}: \mathrm{CH}_{3} \mathrm{OH} \\
(19: 1)\end{array}$ & $\begin{array}{l}\text { Silica Gel 60F } 254 \text { (Merck, } \\
\text { Darmstadt, Germany) }\end{array}$ & 0,5 & {$[63]$} \\
\hline $\begin{array}{l}\mathrm{CHCl}_{3}: \mathrm{CH}_{3} \mathrm{OH}(9: 1) \text { or } \mathrm{CHCl}_{3}: \mathrm{CH}_{3} \mathrm{OH}: \\
\mathrm{H}_{2} \mathrm{O}(65: 30: 5)\end{array}$ & $\begin{array}{l}\text { Silica Gel 60F } 254 \text { (Merck, } \\
\text { Darmstadt, Germany) }\end{array}$ & 0,53 & {$[64]$} \\
\hline $\begin{array}{l}\mathrm{C}_{4} \mathrm{H}_{8} \mathrm{O}_{2}: \mathrm{CH}_{3} \mathrm{OH}: \mathrm{H}_{2} \mathrm{O} \\
(100: 6: 4)\end{array}$ & $\begin{array}{c}\text { Silica Gel } 60 \mathrm{G} \text { and water at } \\
\text { the ratio of } 1: 1\end{array}$ & 0.91 & [65] \\
\hline
\end{tabular}

High-performance chromatography (HPLC) with different detection methods has been used for purification (preparative). It has been widely used to measure and quantify (analysis) Scopoletin (Table 4) [17,25,37,61,67-74].

Table 4. Analytical Method of Scopoletin by HPLC.

\begin{tabular}{|c|c|c|c|c|c|}
\hline UV Detection & Mobil phase & $\begin{array}{c}\text { Flow Rate } \\
(\mathrm{ml} / \mathrm{min})\end{array}$ & Rt (min) & Column & Reference \\
\hline $254 \mathrm{~nm}$ & $\begin{array}{l}0,1 \% \text { formic acid in water } \\
\text { (eluant A) and ACN (eluant B) }\end{array}$ & 1,0 & 12.5 & $\begin{array}{c}\mathrm{C} 18(250 \times 4.6 \mathrm{~mm}, 5 \\
\mu \mathrm{m})\end{array}$ & [17] \\
\hline $350 \mathrm{~nm}$ & $\mathrm{CH} 3 \mathrm{COONa}: \mathrm{C}_{2} \mathrm{H}_{3} \mathrm{~N}(80: 20)$ & 1.0 & 5.497 & $\begin{array}{c}\mathrm{C} 18(4,6 \mathrm{~mm} \times 150 \\
\mathrm{mm}, 5 \mu \mathrm{m})\end{array}$ & [25] \\
\hline $254 \mathrm{~nm}$ & $\begin{array}{l}\text { 0,01M acetic acid: acetonitrile: } \\
\text { methanol }(60: 20: 20)\end{array}$ & 1,0 & 4.3 & $\begin{array}{c}\mathrm{C} 18(250 \times 4.6 \mathrm{~mm}, 5 \\
\mu \mathrm{m})\end{array}$ & [37] \\
\hline $366 \mathrm{~nm}$ & $\begin{array}{llll}\mathrm{CH}_{3} \mathrm{OH}: & \mathrm{H}_{2} \mathrm{O} & (0.1 & \% \mathrm{v} / \mathrm{v} \\
\mathrm{HCOOH}) ; 3: 7 & & \\
\end{array}$ & 1.0 & 19.579 & $\begin{array}{c}\mathrm{C} 18(8 \mathrm{~mm} \times 4 \mathrm{~mm}, 5 \\
\mu \mathrm{m})\end{array}$ & [61] \\
\hline $345 \mathrm{~nm}$ & $\begin{array}{l}\text { Glacial acetic acid }(0.5 \%): \\
\text { Methanol }(26 \%): \text { Deionised } \\
\text { water }(55 \%)\end{array}$ & 1.0 & 16.35 & $\begin{array}{c}(\mathrm{C} 18)(250 \mathrm{~mm} \times 4.60 \\
\mathrm{mm}, 5 \mu \mathrm{l})\end{array}$ & [67] \\
\hline $345 \mathrm{~nm}$ & $\begin{array}{l}\mathrm{CH}_{3} \mathrm{OH} \text { and } \mathrm{H}_{2} \mathrm{O}(49: 51, \mathrm{v} / \mathrm{v}) \\
0.05 \%(\mathrm{v} / \mathrm{v}) \mathrm{H}_{3} \mathrm{PO}_{4}\end{array}$ & 1.0 & 5.1 & $\begin{array}{c}\mathrm{C} 18(4,6 \mathrm{~mm} \times 150 \\
\mathrm{mm}, 5 \mu \mathrm{m})\end{array}$ & [68] \\
\hline $300 \mathrm{~nm}$ & $\begin{array}{l}\text { 55: } 45\left(\% \text { v/v) } \mathrm{CH}_{3} \mathrm{OH}: \mathrm{H}_{2} \mathrm{O}\right. \\
\left(0.1 \% \mathrm{CH}_{3} \mathrm{COOH}\right)\end{array}$ & 1.0 & 4.6 & $\begin{array}{c}\mathrm{C} 18(250 \mathrm{~mm} \times 4.6 \\
\mathrm{mm}, 5 \mu \mathrm{m})\end{array}$ & [69] \\
\hline $220 \mathrm{~nm}$ & $\begin{array}{lll}\mathrm{CH}_{3} \mathrm{OH}: & \mathrm{H}_{2} \mathrm{O} & (0.05 \% \\
\mathrm{HCOOH}) & & \\
\end{array}$ & 1.0 & 7.87 & $\begin{array}{c}\mathrm{C} 18(250 \mathrm{~mm} \times 4.6 \\
\mathrm{mm}, 5 \mu \mathrm{m})\end{array}$ & [70] \\
\hline $345 \mathrm{~nm}$ & $\begin{array}{l}\text { (A) } \mathrm{H}_{2} \mathrm{O}: \mathrm{H}_{3} \mathrm{PO}_{4}(99.7: 0.3 \% \\
\text { v/v) (B) } \mathrm{ACN}: \mathrm{H}_{2} \mathrm{O}: \mathrm{H}_{3} \mathrm{PO}_{4} \\
(79.9: 20: 0.3 \% \text { v/v) Method- } \\
\mathrm{A}: \mathrm{B}(75: 25 \% \mathrm{v} / \mathrm{v})\end{array}$ & 1.0 & 6.03 & $\begin{array}{c}\mathrm{C} 18(250 \times 212 \mathrm{~mm} \\
15 \mu \mathrm{m})\end{array}$ & [71] \\
\hline $350 \mathrm{~nm}$ & $\begin{array}{l}0,01 \quad \mathrm{M} \text { sodium } \text { acetate: } \\
\text { acetronitrile }(80: 20, \mathrm{v} / \mathrm{v}) \text {; } \\
\text { isokratik }\end{array}$ & 1,0 & 5.585 & $\begin{array}{l}\mathrm{C} 18(4.6 \mathrm{~mm} \times 150 \\
\mathrm{mm}, 5.0 \mu \mathrm{m})\end{array}$ & [72] \\
\hline $280 \mathrm{~nm}$ & $\begin{array}{l}0,1 \%(\mathrm{v} / \mathrm{v}) \text { Trifluoroacetic } \\
\text { acid in water (A) dan } 100 \% \\
\text { acetronitrile (B); gradien }\end{array}$ & 1,0 & 11.812 & $\begin{array}{c}\mathrm{C} 18(250 \times 4.6 \mathrm{~mm}, 5 \\
\mu \mathrm{m})\end{array}$ & [73] \\
\hline
\end{tabular}




\begin{tabular}{c|l|c|c|c|c}
\hline UV Detection & \multicolumn{1}{|c|}{ Mobil phase } & $\begin{array}{c}\text { Flow Rate } \\
(\mathbf{m l} / \mathbf{m i n})\end{array}$ & Rt (min) & Column & Reference \\
\hline $230 \mathrm{~nm}$ & $\begin{array}{l}\text { water (A) and methanol (B) } \\
\text { both contain 0.1\% TFA: 30- } \\
\text { 65\% B; gradien }\end{array}$ & 1,0 & 13.28 & $\begin{array}{c}\text { ACE prep-column } \\
(150 \times 21.2 \mathrm{~mm}, 10 \\
\mu \mathrm{m})\end{array}$ & {$[74]$} \\
\end{tabular}

\section{Methods}

Searches for this review were conducted online at Google Scholar and Google Patent. The search keywords used were: "Scopoletin" and "Isolation" and "Analysis" and "Pharmacological Effects". Literature reviews were obtained from journals and research reports in March-August 2020. The number of the reviewed literature was 103 journals related to their relevance and fulfilling the search keywords, determined independently by three authors, only those selected by at least two authors to be reviewed and put in the script.

\section{Results and Discussion}

Scopoletin (Figure 1) includes simple coumarin, which is derived from 1,2benzopyrone in plants high in the common plant phenylpropane pathway. The coumarin structure (2H-1-benzopyran-2-one) is formed by ortho-hydroxylation of cinnamic acid, trans/cis side-chain isomerization, and lactonization. O-hydroxylation is a key step in coumarin biosynthesis as a branch point of lignin biosynthesis [3].

Scopoletin has several pharmacological activities, namely antihepatotoxicity [5], antibacterial [16], antithyroid [20], antifungal [27,34,35], antitubercular [36], anti-migratory [37], antihypertensive [38,39], antioxidant [40], antiproliferative [41], antiinflamation $[17,42,43,44,45,46,47]$, neurological $\quad[48,49,50,51,52,53]$, antidopaminergic and antiadrenergic [54], antidiabetic [55], antihyperuricemic [56]. In this research [5] scopoletin can significantly reduce the release of glutamate pyruvate transaminase and sorbitol dehydrogenase by $53 \%$ and $58 \%$ in the initial carbon tetrachloride poisoning of rat liver cells at doses of 1 to $50 \mathrm{M}$. Scopoletin 1,4 $\mu \mathrm{mol} / \mathrm{g}$ in bark (200 g dry weight) showed activity as an anti-pseudomonas preparation [16]. Taking Scopoletin (1.00 $\mathrm{mg} / \mathrm{kg}$, p.o.) daily for 7 consecutive days can reduce serum thyroid hormone levels and glucose 6 phosphatase and sugar activity [20]. Scopoletin has excellent inhibitory activity on ordering AGEs, with an IC50 value of $2.93 \mu \mathrm{M}$ and an RLAR inhibitory activity with an IC50 value of $22.5 \mu \mathrm{M}$ [27]. The minimum concentration inhibitory ranges were $0.07 \pm 0.00 \mu \mathrm{g} / \mathrm{ml}$ and $0.15 \pm 0.00 \mu \mathrm{g} / \mathrm{ml}$. The antifungal activity of scopoletin can extract some destructive fungi in food [34]. The minimum inhibitory concentration (MIC90) of scopoletin against Candida was 67.22, and 119 $\mu \mathrm{g} / \mathrm{mL}$ was effective against Candida. And antifungal activity [35]. At a dose of $40 \mathrm{mg} / \mathrm{ml}$, scopoletin can be used as an anti-tuberculosis drug for Mycobacterium tuberculosis strain H37Rv [36]. Scopoletin $0.58 \%$ (w / w) can inhibit viability, move to MCF-7 cells, and be developed as an anticancer drug for breast cancer [37]. Scopoletin $0.46+0.05 \%$ can significantly reduce blood pressure in hypertensive rats [38]. Scopoletin at doses of 1, 3, and $10 \mathrm{mg} / \mathrm{kg}$ decreased IL-4 type I levels, and Scopoletin at doses of $10 \mathrm{mg} / \mathrm{kg}$ decreased serum levels [39]. Scopoletin $(17.4 \mu \mathrm{g} / \mathrm{mL})$ showed potential antioxidant activity [40]. The antiproliferative effect of scopoletin on all cancer cell lines (IC50 103 and above 600 $\mu \mathrm{g} / \mathrm{ml}$ ) was reduced [41]. Scopoletin $0.62 \mu \mathrm{mol} / \mathrm{g}$ inhibited nitric oxide (NO) production in a manner dependent on lipopolysaccharide-induced RAW 264.7 (LPS) macrophage cell concentration. It was shown that quinones were induced in 1c1c7 Reductase (QR) hepatocyte culture [17]. Scopoletin $100 \mathrm{mg} / \mathrm{kg}$ showed anti-inflammatory activity in rat ear edema caused by croton oil 
[42]. Scopoletin $(0.63-2.50 \mathrm{~g} / \mathrm{kg})$ is a potential preventive and therapeutic agent for inflammatory gastroesophageal diseases, mainly through its antisecretory and promoter activities, including serotonin inhibition, free radicals, and inflammation-mediated cytokine effects [43]. Scopoletin showed significant activity on LDL oxidation (IC50 $=10.2 \mu \mathrm{M})$, and exerted a vascular anti-inflammatory effect on human endothelial cells EA.hy 926 activated by TNF- $\alpha$ [44]. Scopoletin $(2.0,10.0,50.0 \mathrm{mg} / \mathrm{kg})$ demonstrated that inhibition of nuclear factor$\kappa \mathrm{B}$ and mitogen-activated protein kinase signaling pathways involved in anti-inflammatory activity and regulation of the excitatory/inhibitory balance may be associated with anxiolytic effects [45]. It has an inhibitory effect on HNE (human neutrophil elastase) activity, with IC50 values ranging from 3.6 to $74.3 \mu \mathrm{M}$ [46]. Scopoletin can prevent oxidative stress and apoptosis, as well as activate Nrf2 signaling [47]. Scopoletin (10 mg/kg, po) exhibits effects such as antidepressant depending on serotonergic drugs (5-HT2A receptors), noradrenergic systems ( $\alpha 1$ - and $\alpha 2$-adrenergic receptors), and dopaminergic drugs (dopamine D1 and D2 receptors) [48]. Scopoletin, which is confirmed to be the extract's main component, is a GABA-T inhibitor (IC50 = 10.57 M) [49]. The decrease in Bid, Bax, and caspase-9 expression induced by scopoletin will decrease cleaved caspase-3 expression, inhibit cleaved PARP expression, and ultimately inhibit the mitochondrial apoptotic pathway [50]. Scopoletin $100 \mathrm{mg} / \mathrm{kg}$ indicates that Scopoletin provides neuroprotection, reduces neuronal apoptosis, and improves neuronal autophagy [51]. The IC50 concentrations of scopoletin inhibited the AChE and BuChE enzymes were 5.34 and $9.11 \mu \mathrm{M}$, respectively [52]. Initial treatment of SH-SY5Y cells with 5 $\mathrm{mM}$ scopoletin can prevent $\mathrm{H}_{2} \mathrm{O}_{2}$ induced cell death and reduce levels of apoptotic cells and ROS [53]. The baseline dose for Eastern mice $(<200 \mu \mathrm{g} / \mathrm{ml})$ showed anti-dopaminergic and anti-adrenergic activity in mice [54]. Scopoletin has a diabetes-stimulating effect. It can stimulate GLUT4 transport and regulate glucose uptake via plasma membrane activation of PI3K and AMPK pathways in 3T3-L1 adipocytes [55]. After continuous oral administration, Scopoletin exhibits a weak urate reduction effect. Sphingolipids have an inhibitory effect on XOD activity in serum and liver [56].

The separation process begins with an extraction process designed to attract the scopoletin compounds present in the plant. According to several studies, the most widely used solvent is methanol. This is because these compounds are relatively easy to dissolve in these compounds. The first extraction process in traditional separation is usually carried out by immersion method for \pm 72 hours. The solvent used enters the cell through the simple cell wall containing scopoletin. The cell content is dissolved due to differences. The concentration between the solution inside and outside the cell. The high concentration solution will be added and replaced with a low concentration solvent (diffusion process). Other extraction methods (such as the Soxhlet extraction method) have been carried out at temperatures of $40^{\circ} \mathrm{C}$ to 60 ${ }^{\circ} \mathrm{C}$, and the reflux method has been used. The extraction method, with the help of heating, will speed up the dissolving process. After heating, the particles at high temperatures will move faster than at low temperatures. The contact between the solute and the solvent is more effective. Other extraction methods include using supercritical $\mathrm{CO} 2$ at $80{ }^{\circ} \mathrm{C}$ to $85^{\circ} \mathrm{C}$ for $1-2$ hours. The Soxhlet extraction method was used $0.93 \%$ to obtain the extraction results [62] from the process of extracting scopoletin compounds. As observed from the scopoletin separation process results in Table 2 , the number of isolates obtained was significantly different. Separate $0.3 \%$ Artemisia annua stems by diafiltration for 6-8 hours to obtain isolates, then using column chromatography and dissolving scopoletin in a methanol-chloroform mixture to obtain extract [1]. 
Analytical methods that can assist the identification process of scopoletin compounds include thin layer chromatography as initial identification. Ultraviolet-visible spectrophotometer and HPLC can be used for further identification. High-performance liquid chromatography can identify target compounds based on the following principle: when a sample moves through the stationary phase (which can be either solid or liquid), the sample will be taken up by the mobile phase (it can be a liquid or a gas). Analytical methods that contribute to the process The various components in the sample are separated according to their different affinities to the stationary phase. Components that can interact strongly with the stationary phase move more slowly, so they can be separated from other components that interact weakly. In addition, several complementary identifications must be carried out to identify the structure of the compounds obtained from the separation process, for example, using infrared-FT, nuclear magnetic resonance, and mass spectrometry.

TLC (Thin Layer Chromatography) is a qualitative test to determine the purity of a compound. Based on a number of studies (Table 3), good thin layer chromatography results were obtained, namely the ratio of $\mathrm{C}_{4} \mathrm{H}_{8} \mathrm{O}_{2}: \mathrm{CH}_{3} \mathrm{OH}: \mathrm{H}_{2} \mathrm{O}$ (100: 6: 4), and an Rf value of 0.91 [65]. For several compounds in multiple eluents, the $\mathrm{Rf}$ value is very typical. The $\mathrm{Rf}$ value is the ratio of the eluent distance to the mobile phase on the TLC plate. Compounds with a greater Rf show lower polarity, and vice versa. This is because the stationary phase is polar. The more polar compounds are held firmly in the stationary phase, resulting in a lower Rf value. A good TLC $\mathrm{Rf}$ is 0.2 to 0.8 . If $\mathrm{Rf}$ is too high, all you have to do is reduce the eluent's polarity and vice versa. The value of $\mathrm{Rf}$ can be used as proof of multiple identifications. If the Rf value has the same value, it can be said that the compound has the same or similar properties as a comparison. The success of the separation depends on the difference in the components' solubility to be separated in the solvent [45]. Most of the coumarin compounds are active against ultraviolet rays. This is because coumarin has a conjugated double bond. It is known that ultraviolet absorbent rays can either absorb conjugated bonds or have a chromophore. Scopoletin is a coumarin compound, showing blue fluorescence when exposed to $365 \mathrm{~nm}$ of ultraviolet light [75]. Staining under $365 \mathrm{~nm}$ ultraviolet light indicates that the compound has at least two conjugated double bonds. This appearance is due to the strength of the interaction between ultraviolet light and the chromophore which is bound by additional pigments present in the dye. Visible light fluorescence is the light emitted by these components when electrons are excited from a basic energy level to a higher energy level and then return to their original state when the energy was released. Hence, the visible stain on UV lamps looks very bright due to silica. The gel used does not fluoresce under $365 \mathrm{~nm}$ ultraviolet light [76].

HPLC stands for high-performance liquid and can be described as a method of separating molecules from a liquid medium that is subjected to high pressure. The function of HPLC is to determine or measure or analyze the levels of active ingredients in a sample (drugs, food, or herbs). Based on the results of several studies (Table 4), aroma pole analysis (2013) Vipul et al. (2013) showed that the retention time of scopoletin was 19,583, which indicated that the compounds of scopoletin and standard scopoletin were the same, namely the retention time of 19,579 minutes [46].

Table 5. The data from the FTIR spectrum of standard Scopoletin.

\begin{tabular}{c|c|c} 
Peaks $\left(\mathbf{c m}^{-\mathbf{1}}\right)$ & Functional group & Reference \\
\hline 3337.44 & O-H Alcohol group present & \\
\hline 2850.97 & C-H group present \\
\hline 1702.90 & Carbonyl C=O group present
\end{tabular}




\begin{tabular}{c|c|c} 
Peaks $\left(\mathbf{c m}^{-\mathbf{1}}\right)$ & Functional group & Reference \\
\hline 1628.09 & $\mathrm{CH}=\mathrm{CH}$ group present & \\
\hline 1565.06 & Benzene ring present & \\
\hline 1510.53 & Benzene ring present & \\
\hline 861.46 & Due to disubstitution of benzene &
\end{tabular}

Fourier transformed infrared (FTIR) spectroscopy can quickly measure functional groups without damage and is able to analyze several components simultaneously. Basically, FTIR spectroscopy is the same as dispersion IR spectroscopy. What distinguishes it is the development in the optical system before the infra-red beam passes through the sample. Table 5 shows the data obtained from standard FTIR spectroscopy and possible scopoletin functional groups. In infrared spectrum analysis [21], the peak was at $3341.44 \mathrm{~cm}^{-1}$, which is the result of the $\mathrm{OH}$ alcohol group present, the peak of 2875.05 is the result of the $\mathrm{CH}$ group present, the peak of 1703.42 is the result of the carbonyl $\mathrm{C}=\mathrm{O}$ group present, at the peak of 1606.75 is the result of the $\mathrm{CH}=\mathrm{CH}$ group present, and at the peak of $1568.83 ; 1511.16 ; 861.50$ is the result of the benzene ring present. In the study [30] infrared spectrum analysis, the peak at 3318 was the result of the $\mathrm{OH}$ alcohol group present, the peak 2926-290 was the result of the $\mathrm{CH}$ group present, the peak 1698 was the result of the carbonyl $\mathrm{C}=\mathrm{O}$ group present, the peak 1602 was the result of the $\mathrm{CH}=\mathrm{CH}$ group present, as well as the peaks 1567.68 and 1517.01 are the results of the benzene ring present. In a study [32] infrared spectrum analysis, peaks at 3325 (vO-H), 3055 (vC-H of C = CH), 2920 (vC-H of -CH3, CH2), 2850 (vC-H of -OCH3), 1705 $(v \mathrm{C}=\mathrm{O})$ of $\delta$ lactone, $1604(\mathrm{vC}=\mathrm{C}$ of aromatic ring). In a study [33] infrared spectrum analysis, peaks at 3325 (vOH of the alcoholic group), $3001(\mathrm{v}=\mathrm{CH}$ stretching), 2848 (vC-H stretching of CH3), 1705 ( $\mathrm{vC}=\mathrm{O}$ stretching), 1612; 1566; $1504(\mathrm{vC}=\mathrm{C}$ stretching of cumarone and benzene), 1427 (vC-H of $\mathrm{CH} 3$ group), 1288; 1134 (vC-O stretching of $\mathrm{OH}$ ), and 864 (Disubstitution of benzene).

Table 6. The data from the NMR spectrum of standard Scopoletin.

\begin{tabular}{|c|c|c|c|}
\hline \multicolumn{4}{|c|}{ Standard Scopoletin } \\
\hline $\begin{array}{l}\text { No. of } \mathbf{H} \\
\text { atom }\end{array}$ & $\begin{array}{c}\delta \text { value, } \\
\text { ppm }\end{array}$ & $\begin{array}{c}\text { Integration, Multiplicity } \\
(\mathbf{J}, \mathbf{H Z})\end{array}$ & Reference \\
\hline 3 & 6.23 & $1 \mathrm{H}, \mathrm{d}(9.2)$ & \multirow{4}{*}[21]{} \\
\hline 4 & 7.88 & $1 \mathrm{H}, \mathrm{d}(9.6)$ & \\
\hline 5 & 7.14 & $1 \mathrm{H}, \mathrm{S}$ & \\
\hline 8 & 6.79 & $1 \mathrm{H}, \mathrm{S}$ & \\
\hline C-6-OMe & 3.93 & $3 \mathrm{H}, \mathrm{S}$ & \\
\hline
\end{tabular}

Table 6 shows the data obtained from the scopoletin NMR spectrum standard. In the study [21] the ${ }^{1} \mathrm{H}$ NMR spectrum showed two double peaks, and the coupling constant at $\delta 6.22$ and 7.88 ppm was $9.2 \mathrm{~Hz}$, defined as $\mathrm{H}-3$ and $\mathrm{H}-4$, respectively. At $\delta 7.13$ and 6.79 ppm showed two single aromatic peaks defined as $\mathrm{H}-5$ and $\mathrm{H}-8$, and at $\delta 3.93 \mathrm{ppm}$ showed methoxy groups. In the study [32] the ${ }^{1} \mathrm{H}$ NMR spectrum showed two double peaks, and the coupling constant at $\delta 6.2$ and 7.6 ppm was $9 \mathrm{~Hz}$, defined as $\mathrm{H}-3$ and $\mathrm{H}-4$, respectively. At $\delta 6,8$ and 6,9 ppm showed two single aromatic peaks defined as H-5 and H-8 and at $\delta 3,7$ ppm showed methoxy group. The study [77] ${ }^{1} \mathrm{H}$ NMR spectrum showed two double peaks, and the coupling constant at $\delta 6.22$ and $7.88 \mathrm{ppm}$ was $9.5 \mathrm{~Hz}$, defined as $\mathrm{H}-3$ and $\mathrm{H}-4$, respectively. At $\delta 7.12$ and 6.79 ppm showed two single aromatic peaks defined as $\mathrm{H}-5$ and $\mathrm{H}-8$, and at $\delta 3.97 \mathrm{ppm}$ showed methoxy groups. The study [78] ${ }^{1} \mathrm{H}$ NMR spectrum showed two double peaks, and the coupling constant at $\delta 6.09$ and 7.83 ppm was $9.5 \mathrm{~Hz}$, defined as H-3 and H-4, respectively. At $\delta 7.10$ and 6.65 ppm showed two single aromatic peaks defined as $\mathrm{H}-5$ and $\mathrm{H}-8$, and at $\delta 3.77 \mathrm{ppm}$ 
indicated a methoxy group. In the study [79] the ${ }^{1} \mathrm{H}$ NMR spectrum showed two double peaks, and the coupling constant at $\delta 6.01$ and 7.69 ppm was $12 \mathrm{~Hz}$, defined as $\mathrm{H}-3$ and $\mathrm{H}-4$, respectively. At $\delta 6.86$ and $6.61 \mathrm{ppm}$ showed two single aromatic peaks defined as $\mathrm{H}-5$ and $\mathrm{H}-$ 8 and at $\delta 3.81 \mathrm{ppm}$ indicated a methoxy group. In the study [80] the ${ }^{1} \mathrm{H}$ NMR spectrum showed two double peaks, and the coupling constant at $\delta 6.18$ and 7.50 ppm was $9.2 \mathrm{~Hz}$, defined as $\mathrm{H}$ 3 and $\mathrm{H}-4$, respectively. At $\delta 6.77$ and 6.84 ppm showed two single aromatic peaks defined as $\mathrm{H}-5$ and $\mathrm{H}-8$, and at $\delta 3.88 \mathrm{ppm}$ showed methoxy groups.

Table 7. The molecular weight data from the mass spectrum of standard Scopoletin and isolated compound V.

\begin{tabular}{c|c|c|c} 
No. Sample & M-1 Peak & Molecular weight & Reference \\
\hline Standard Scopoletin & 191.10 & 192.10 & {$[21]$} \\
\hline Isolated Compound V & 191.10 & 192.10 & {$[21]$}
\end{tabular}

Table 7 shows the molecular weight data of the mass spectra of the standard Scopoletin and isolated compounds $\mathrm{V}$. The mass spectrum of the standard compounds separated from Scopoletin and V shows the M-1 peak at 191.10, which indicates the same molecular weight of 192.10. Therefore, it can be determined that the isolated compound V was Scopoletin [21].

\section{Conclusions}

Based on the literature review results, scopoletin can be extracted from Morinda citrifolia L, Helichrysum italicum, Convolvulus pluricaulis, Artemisia annua, Lasianthus lucidus, and Morus alba L. The highest yield of scopoletin extract was found in noni (Morinda citrifolia L) namely $0.93 \%$ using the Soxhlet extraction method. The isolation process of scopoletin from Artemisia аппиа by column chromatography followed by recrystallization gave the highest isolate yield that was $0.3 \%$. Scopoletin identification can be made using Thin Layer Chromatography (TLC), High-Performance Liquid Chromatography (HPLC) where the HPLC system of 0,01M acetic acid: acetonitrile: methanol (60:20:20) mobile phase, UV detector at $254 \mathrm{~nm}, \mathrm{C} 18(250 \times 4.6 \mathrm{~mm}, 5 \mu \mathrm{m})$ column, $1 \mathrm{ml} / \mathrm{min}$ flow rate has the fastest analytical time among other HPLC system. Fourier Transform Infrared Spectrophotometer (FTIR), Nuclear Magnetic Resonance, and Mass Spectrometry can be used to identify. Based on in vitro studies, scopoletin has pharmacological activities, including as an antihepatotoxicity, antibacterial, antifungal, antitubercular, and antioxidant. Pharmacological activities proved in vivo antithyroid, antihypertensive, anti-proliferative, anti-inflammatory, neurological, anti-dopaminergic and anti-adrenergic, antidiabetic, and antihyperuricemic activities.

\section{Funding}

This research received no external funding.

\section{Acknowledgments}

The authors declare no acknowledgments.

\section{Conflicts of Interest}

The authors declare no conflict of interest. 


\section{References}

1. Jain, D.C.; Pant, N.; Gupta, M.M.; Bhakuni, R.S.; Verma, R.K.; Tandon, S.; Gupta, S.K.; Tewari, A.; Kahol, A.P.; Kumar, S. Process for the isolation of compound scopoletin useful as nitric oxide synthesis inhibitor. Google Patents: 2002.

2. Li, J.; Wu, J. Scopolin, a glycoside form of the phytoalexin scopoletin, is likely involved in the resistance of Nicotiana attenuata against Alternaria alternata. J. Plant Pathol. 2016, 641-644, https://doi.org/10.4454/JPP.V98I3.006.

3. Gnonlonfin, G.J.B.; Sanni, A.; Brimer, L. Review Scopoletin - A Coumarin Phytoalexin with Medicinal Properties. Crit. Rev. Plant Sci. 2012, 31, 47-56, https://doi.org/10.1080/07352689.2011.616039.

4. Shaw, C.-Y.; Chen, C.-H.; Hsu, C.-C.; Chen, C.-C.; Tsai, Y.-C. Antioxidant properties of scopoletin isolated from Sinomonium acutum. Phytother. Res. 2003, 17, 823-825, https://doi.org/10.1002/ptr.1170.

5. Kang, S.Y.; Sung, S.H.; Park, J.H.; Kim, Y.C. Hepatoprotective activity of scopoletin, a constituent ofSolanum lyratum. Arch. Pharmacal Res. 1998, 21, 718, https://doi.org/10.1007/BF02976764.

6. Oliveira, E.J.; Romero, M.A.; Silva, M.S.; Silva, B.A.; Medeiros, I.A. Intracellular calcium mobilization as a target for the spasmolytic action of scopoletin. Planta Med. 2001, 67, 605-608., https://doi.org/10.1055/s2001-17355.

7. Kang, T.-H.; Pae, H.-O.; Jeong, S.-J.; Yoo, J.-C.; Choi, B.-M.; Jun, C.-D.; Chung, H.-T.; Miyamoto, T.; Higuchi, R.; Kim, Y.-C. Scopoletin: an inducible nitric oxide synthesis inhibitory active constituent from Artemisia feddei. Planta Med. 1999, 65, 400-403, https://doi.org/10.1055/s-1999-14014.

8. Jokić, S.; Rajić, M.; Bilić, B.; Molnar, M. Supercritical Extraction of Scopoletin from Helichrysum italicum (Roth) G. Don Flowers. Phytochem. Anal. 2016, 27, 290-295, https://doi.org/10.1002/pca.2630.

9. Wheatley, C.C.; Schwabe, W.W. Scopoletin Involvement in Post-Harvest Physiological Deterioration of Cassava Root (Manihot esculenta Crantz). J. Exp. Bot. 1985, 36, 783-791, https://doi.org/10.1093/jxb/36.5.783.

10. Sethiya, N.K.; Trivedi, A.; Mishra, S.H. Rapid validated high performance thin layer chromatography method for simultaneous estimation of mangiferin and scopoletin in Canscora decussata (South Indian Shankhpushpi) extract. Revista Brasileira de Farmacognosia 2015, 25, 193-198, https://doi.org/10.1016/j.bjp.2015.04.002.

11. Hussein Ahmed, O.; Hamad, M.; Jaafar, N. Phytochemical investigation of Chenopodium Murale (family: Chenopodiaceae) cultivated in Iraq, isolation and identification of scopoletin and gallic acid. Asian Journal of Pharmaceutical and Clinical Research 2017, 10, 70, https://doi.org/10.22159/ajpcr.2017.v10i11.20504.

12. Pan, R.; Gao, X.; Lu, D.; Xu, X.; Xia, Y.; Dai, Y. Prevention of FGF-2-induced angiogenesis by scopoletin, a coumarin compound isolated from Erycibe obtusifolia Benth, and its mechanism of action. Int. Immunopharmacol. 2011, 11, 2007-2016, https://doi.org/10.1016/j.intimp.2011.08.012.

13. Jamuna, S.; Karthika, K.; Paulsamy, S.; Thenmozhi, K.; Kathiravan, S.; Venkatesh, R. Confertin and scopoletin from leaf and root extracts of Hypochaeris radicata have anti-inflammatory and antioxidant activities. Industrial Crops and Products 2015, 70, 221-230, https://doi.org/10.1016/j.indcrop.2015.03.039.

14. Ahn, M.-J.; Hur, S.-J.; Kim, E.-H.; Lee, S.H.; Shin, J.S.; Kim, M.-K.; Uchizono, J.A.; Whang, W.-K.; Kim, D.-S. Scopoletin from Cirsium setidens Increases Melanin Synthesis via CREB Phosphorylation in B16F10 Cells. Korean J Physiol Pharmacol 2014, 18, 307-311, https://doi.org/10.4196/kjpp.2014.18.4.307.

15. Prabowo, W.C.; Wirasutisna, K.R.; Insanu, M. Isolation and characterization of 3 -acetyl aleuritolic and scopoletin from stem bark of Aleurites molucana L. Will. International Journal of Pharmacy and Pharmaceutical Sciences 2013, 5, 851-853.

16. Napiroon, T.; Bacher, M.; Balslev, H.; Tawaitakham, K.; Santimaleeworagun, W.; Vajrodaya, S. Scopoletin from Lasianthus lucidus Blume (Rubiaceae): A potential antimicrobial against multidrug-resistant Pseudomonas aeruginosa. Journal of Applied Pharmaceutical Science 2018, 8, 1-6, https://doi.org/10.7324/JAPS.2018.8901.

17. Nitteranon, V.; Zhang, G.; Darien, B.J.; Parkin, K. Isolation and synergism of in vitro anti-inflammatory and quinone reductase (QR) inducing agents from the fruits of Morinda citrifolia (noni). Food Res. Int. 2011, 44, 2271-2277, https://doi.org/10.1016/j.foodres.2010.11.009.

18. Reigh, D.L.; Wender, S.H.; Smith, E.C. Scopoletin: A substrate for an isoperoxidase from Nicotiana tabacum tissue culture W-38. Phytochemistry 1973, 12, 1265-1268, https://doi.org/10.1016/0031-9422(73)80550-3.

19. Khan, N.; Hossain, M.S. Scopoletin and $\beta$-sitosterol glucoside from roots of Ipomoea digitata. Journal of Pharmacognosy and Phytochemistry 2015, 4, 05-07.

20. Panda, S.; Kar, A. Evaluation of the antithyroid, antioxidative and antihyperglycemic activity of scopoletin from Aegle marmelos leaves in hyperthyroid rats. Phytotherapy Research: An International Journal Devoted to Pharmacological and Toxicological Evaluation of Natural Product Derivatives 2006, 20, 1103-1105.

21. Bhatt Mehul, K.; Dholwani Kishor, K.; Saluja Ajay, K. Isolation and structure elucidation of scopoletin from Ipomoea reniformis (Convolvulaceae). Journal of Applied Pharmaceutical Science 2011, 1, 138-144. 
22. Lee, S.-H.; Ding, Y.; Yan, X.T.; Kim, Y.-H.; Jang, H.-D. Scopoletin and Scopolin Isolated from Artemisia iwayomogi Suppress Differentiation of Osteoclastic Macrophage RAW 264.7 Cells by Scavenging Reactive Oxygen Species. J. Nat. Prod. 2013, 76, 615-620, https://doi.org/10.1021/np300824h.

23. Darmawan, A.; Kosela, S.; Kardono, L.B.S.; Syah, Y.M. Scopoletin, a coumarin derivative compound isolated from Macaranga gigantifolia Merr. Journal of Applied Pharmaceutical Science 2012, 2, 175.

24. Tripathi, A.K.; Bhakuni, R.S.; Upadhyay, S.; Gaur, R. Insect feeding deterrent and growth inhibitory activities of scopoletin isolated from Artemisia annиa against Spilarctia obliqua (Lepidoptera: Noctuidae). Insect Sci. 2011, 18, 189-194, https://doi.org/10.1111/j.1744-7917.2010.01350.x.

25. Ojewole, J.A.O. Effects of Scopoletin on Autonomic Transmissions. International Journal of Crude Drug Research 1984, 22, 81-93, https://doi.org/10.3109/13880208409070657.

26. Arcos, M.L.B.; Cremaschi, G.; Werner, S.; Coussio, J.; Ferraro, G.; Anesini, C. Tilia cordata Mill. extracts and scopoletin (isolated compound): differential cell growth effects on lymphocytes. Phytother. Res. 2006, 20, 34-40, https://doi.org/10.1002/ptr.1798.

27. Carpinella, M.C.; Ferrayoli, C.G.; Palacios, S.M. Antifungal Synergistic Effect of Scopoletin, a Hydroxycoumarin Isolated from Melia azedarach L. Fruits. J. Agric. Food Chem. 2005, 53, 2922-2927, https://doi.org/10.1021/jf0482461.

28. Miller, D.; Sutcliffe, R.; Thauvette, J. Sticker stain formation in hardwoods: Isolation of scopoletin from sugar maple (Acer saccharum Marsh.). Wood Science and Technology 1990, 24, 339-344, https://doi.org/10.1007/BF00227054.

29. Kurdekar, R.R.; Hegde, G.R.; Kulkarni, M.V.; Mulgund, G.S. Isolation and characterization of scopoletin-an anticancerous compound from the bark of Hymenodictyon obovatum Wall. Int. J. Pharm. Phytopharmacol. Res. 2014; 3 (6): 469-471

30. Ferdinal, N.; Alfajri, R.; Arifin, B. Isolation and characterization of scopoletin from the bark of fagraea ceilanica Thumb and Antioxidants tests. International Journal on Advanced Science, Engineering and Information Technology 2015, 5, 126-130, https://doi.org/10.18517/ijaseit.5.2.504.

31. Lee, J.; Kim, N.H.; Nam, J.W.; Lee, Y.M.; Jang, D.S.; Kim, Y.S.; Nam, S.H.; Seo, E.-K.; Yang, M.S.; Kim, J.S. Scopoletin from the flower buds of Magnolia fargesii inhibits protein glycation, aldose reductase, and cataractogenesis Ex Vivo. Arch. Pharmacal Res. 2010, 33, 1317-1323, https://doi.org/10.1007/s12272-0100904-Z.

32. Sann, E.E.; Soe, M.M.; Khine, M.M. Isolation And Identification Of Some Phytoconstituents From Leaves Of Morus alba L. And Screening Of Antioxidant Activity. J. Myanmar Acad. Arts Sci. 2020, 18, 401-407. https://doi.org/10.22159/ijpps.2017v9i12.19841.

33. $\mathrm{Nu}, \mathrm{T}$.T. Investigation of Antimicrobial Activity and Isolation of Phytoconstituents from Leaves of Clausena excavata Burm. f.(Pyin-daw-thein). $3^{r d}$ Myanmar Korea Conference Research Journal, 11, 5.

34. Njankouo Ndam, Y.; Nyegue, M.A.; Mounjouenpou, P.; Kansci, G.; Kenfack, M.J.; Eugène, E.E. LC-MS quantification of scopoletin in cassava (Manihot Esculenta Crantz) varieties, local derived foods, and activity on some food spoilage fungi. J. Food Process. Preserv. 2020, 44, e14387, https://doi.org/10.1111/jfpp.14387.

35. Das, S.; Czuni, L.; Báló, V.; Papp, G.; Gazdag, Z.; Papp, N.; Kőszegi, T. Cytotoxic Action of Artemisinin and Scopoletin on Planktonic Forms and on Biofilms of Candida Species. Molecules 2020, 25, 476, https://doi.org/10.3390/molecules25030476.

36. Novie, E.M.; Hendro, W.; Suharyo Hadi, S.; Tri, N.K. Antitubercular Activity Of Extract And Coumpounds Of Noni (Morinda citrifolia Linn). International Journal of Pharmacy and Pharmaceutical Sciences 2017, 9, https://doi.org/10.22159/ijpps.2017v9i12.19841.

37. Noor, A., Gunasekaran, S., \& Vijayalakshmi, M. A. 2018. Improvement of Insulin Secretion and Pancreatic $\beta$-cell Function in Streptozotocin-induced Diabetic Rats Treated with Aloe vera Extract. Article in Pharmacognosy Research. October 2017. Pharmacognosy Research, 10(October), 24-30, https://doi.org/10.4103/pr.pr.

38. Wigati, D.; Anwar, K.; Sudarsono; Nugroho, A.E. Hypotensive activity of ethanolic extracts of Morinda citrifolia L. leaves and fruit in dexamethasone-induced hypertensive rat. J. Evid. Based Complementary Altern. Med. 2017, 22, 107-113, https://doi.org/10.1177/2156587216653660.

39. Aldi, Y.; Yuliandra, Y.; Nasrul, E.; Yanwirasti; Handayani, D.; Bakhtiar, A. Decreased interleukin-4 level of type I hypersensitive mice using scopoloetin isolated from noni fruit (Morinda citrifolia L.). Research Journal Of Pharmaceutical Biological And Chemical Sciences 2015, 6, 1823-1829.

40. Gwak, M.-K.; Choi, H.-S.; Manochai, B.; Hong, J.-H. Extraction Procedures for Free Radical Scavenging Activity from Noni Fruit (Morinda citrifolia). Korean Journal of Medicinal Crop Science 2011, 19, 38-46, https://doi.org/10.7783/kjmcs.2011.19.1.038.

41. Thani, W.; Vallisuta, O.; Siripong, P.; Ruangwises, N. Anti-proliferative and antioxidative activities of Thai noni/Yor (Morinda citrifolia Linn.) leaf extract. The Southeast Asian journal of tropical medicine and public health 2010, 41, 482-489.

42. Ding, Z.; Dai, Y.; Hao, H.; Pan, R.; Yao, X.; Wang, Z. Anti-Inflammatory Effects of Scopoletin and Underlying Mechanisms. Pharm. Biol. 2008, 46, 854-860, https://doi.org/10.1080/13880200802367155.

43. Moon, P.-D.; Lee, B.-H.; Jeong, H.-J.; An, H.-J.; Park, S.-J.; Kim, H.-R.; Ko, S.-G.; Um, J.-Y.; Hong, S.-H.; Kim, H.-M. Use of scopoletin to inhibit the production of inflammatory cytokines through inhibition of the 


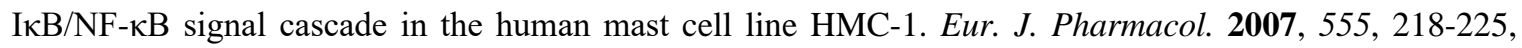
https://doi.org/10.1016/j.ejphar.2006.10.021.

44. Kang, H.R.; Kim, H.J.; Kim, B.; Kim, S.-G.; So, J.-H.; Cho, S.J.; Kwon, H.S. Inhibitory Effect of Scopoletin Isolated from Sorbus commixta on TNF- $\alpha$-Induced Inflammation in Human Vascular Endothelial EA. hy926 Cells through NF- $\kappa$ B Signaling Pathway Suppression. Journal of Life Science 2020, 30, 343-351.

45. Luo, L.; Sun, T.; Yang, L.; Liu, A.; Liu, Q.-q.; Tian, Q.-q.; Wang, Y.; Zhao, M.-g.; Yang, Q. Scopoletin ameliorates anxiety-like behaviors in complete Freund's adjuvant-induced mouse model. Mol. Brain 2020, 13, 15, https://doi.org/10.1186/s13041-020-0560-2.

46. Lee, B.Z.; Kim, K.M.; Chae, S.; Jeong, S.-K.; Lee, S.; Hong, K.; Lee, I.S. New coumarins isolated from the stem bark of Fraxinus rhynchophylla inhibit human neutrophil elastase and LPS-induced inflammation in RAW 264.7 cells. Phytochemistry Letters 2020, 35, 78-83, https://doi.org/10.1016/j.phytol.2019.11.005.

47. Narasimhan, K.K.S.; Jayakumar, D.; Velusamy, P.; Srinivasan, A.; Mohan, T.; Ravi, D.B.; Uthamaraman, S.; Sathyamoorthy, Y.K.; Rajasekaran, N.S.; Periandavan, K. Morinda citrifolia and its active principle scopoletin mitigate protein aggregation and neuronal apoptosis through augmenting the DJ-1/Nrf2/ARE signaling pathway. Oxid. Med. Cell. Longev. 2019, 2019, https://doi.org/10.1155/2019/2761041.

48. Capra, J.C.; Cunha, M.P.; Machado, D.G.; Zomkowski, A.D.E.; Mendes, B.G.; Santos, A.R.S.; Pizzolatti, M.G.; Rodrigues, A.L.S. Antidepressant-like effect of scopoletin, a coumarin isolated from Polygala sabulosa (Polygalaceae) in mice: Evidence for the involvement of monoaminergic systems. Eur. J. Pharmacol. 2010, 643, 232-238, https://doi.org/10.1016/j.ejphar.2010.06.043.

49. Mishra, N.; Oraon, A.; Dev, A.; Jayaprakash, V.; Basu, A.; Pattnaik, A.K.; Tripapthi, S.N.; Akhtar, M.; Ahmad, S.; Swaroop, S. Anticonvulsant activity of Benkara malabarica (Linn.) root extract: In vitro and in vivo investigation. J. Ethnopharmacol. 2010, 128, 533-536, https://doi.org/10.1016/j.jep.2010.01.042.

50. Lee, J.; Cho, H.-J. Neuroprotective Effects of Scopoletin on Neuro-damage caused by Alcohol in Primary Hippocampal Neurons. Biomedical Science Letters 2020, 26, 57-65, https://doi.org/10.15616/BSL.2020.26.2.57.

51. Zhou, R.; Kan, S.; Cai, S.; Sun, R.; Yuan, H.; Yu, B. Scopoletin Activates Adenosine MonophosphateActivated Protein Kinase/Mammalian Target of Rapamycin Signaling Pathway and Improves Functional Recovery after Spinal Cord Injury in Rats. Pharmacology 2020, 105, 349-359, https://doi.org/10.1159/000503866.

52. Kashyap, P.; Ram, H.; Shukla, S.D.; Kumar, S. Scopoletin: Antiamyloidogenic, anticholinesterase, and neuroprotective potential of a natural compound present in argyreia speciosa roots by in vitro and in silico study. Neuroscience insights 2020, 15, https://doi.org/10.1177/2633105520937693.

53. Gay, N.H.; Suwanjang, W.; Ruankham, W.; Songtawee, N.; Wongchitrat, P.; Prachayasittikul, V.; Prachayasittikul, S.; Phopin, K. Butein, isoliquiritigenin, and scopoletin attenuate neurodegeneration via antioxidant enzymes and SIRT1/ADAM10 signaling pathway. RSC Advances 2020, 10, 16593-16606, https://doi.org/10.1039/c9ra06056a.

54. Pandy, V.; Narasingam, M.; Kunasegaran, T.; Murugan, D.D.; Mohamed, Z. Effect of noni (Morinda citrifolia Linn.) fruit and its bioactive principles scopoletin and rutin on rat vas deferens contractility: an ex vivo study. The Scientific World Journal 2014, 2014, https://doi.org/10.1155/2014/909586.

55. Jang, J.H.; Park, J.E.; Han, J.S. Scopoletin increases glucose uptake through activation of PI3K and AMPK signaling pathway and improves insulin sensitivity in 3T3-L1 cells. Nutr. Res. 2020, 74, 52-61, https://doi.org/10.1016/j.nutres.2019.12.003.

56. Zeng, Y.; Ma, Y.; Yang, Z.; Mao, J.; Zheng, Y. Antihyperuricemic efficacy of Scopoletin-loaded Soluplus micelles in yeast extract/potassium oxonate-induced hyperuricemic mice. Drug Dev. Ind. Pharm. 2020, 46, 1550-1557, https://doi.org/10.1080/03639045.2020.1811302.

57. Sichaem, J.; Inthanon, K.; Funnimid, N.; Phontree, K.; Phan, H.-V.-T.; Tran, T.-M.-D.; Niamnont, N.; Srikittiwanna, K.; Sedlak, S.; Duong, T.-H. Chemical Constituents of the Stem Bark of Bombax ceiba. Chem. Nat. Compd. 2020, 56, 909-911, https://doi.org/10.1007/s10600-020-03183-z.

58. National center for Biotechnology Information. Scopoletin. PubChem Compound Database. Available online: https://pubchem.ncbi.nlm.nih.gov/compound/5280460 (accessed on September 2020).

59. Tzeng, T.-C.; Lin, Y.-L.; Jong, T.-T.; Chang, C.-M.J. Ethanol modified supercritical fluids extraction of scopoletin and artemisinin from Artemisia annua L. Sep. Purif. Technol. 2007, 56, 18-24, https://doi.org/10.1016/j.seppur.2007.01.010.

60. Silva, W.P.K.; Deraniyagala, S.A.; Wijesundera, R.L.C.; Karunanayake, E.H.; Priyanka, U.M.S. Isolation of scopoletin from leaves of Hevea brasiliensis and the effect of scopoletin on pathogens of H. brasiliensis. Mycopathologia 2002, 153, 199-202, https://doi.org/10.1023/A:1014910132595.

61. Potterat, O.; Von Felten, R.; Dalsgaard, P.W.; Hamburger, M. Identification of TLC Markers and Quantification by HPLC-MS of Various Constituents in Noni Fruit Powder and Commercial Noni-Derived Products. J. Agric. Food Chem. 2007, 55, 7489-7494, https://doi.org/10.1021/jf071359a.

62. Muenmuang, C.; Narasingha, M.; Phusantisampan, T.; Sriariyanun, M. Chemical Profiling of Morinda citrifolia Extract From Solvent and Soxhlet Extraction Method. In Proceedings of Proceedings of the 6th International Conference on Bioinformatics and Biomedical Science, Singapore, Singapore; 119-123, https://doi.org/10.1145/3121138.3121194. 
63. West, B.J.; Deng, S. Thin layer chromatography methods for rapid identity testing of Morinda citrifolia L.(Noni) fruit and leaf. Adv. J. Food Sci. Technol 2010, 2, 298-302.

64. Potterat, O.; Von Felten, R.; Dalsgaard, P.W.; Hamburger, M. Identification of TLC Markers and Quantification by HPLC-MS of Various Constituents in Noni Fruit Powder and Commercial Noni-Derived Products. J. Agric. Food Chem. 2007, 55, 7489-7494, https://doi.org/10.1021/jf071359a.

65. Nandhasri, P.; Pawa, K.K.; Kaewtubtim, J.; Jeamchanya, C.; Jansom, C.; Sattaponpun, C. Nutraceutical properties of Thai "Yor" Morinda citrifolia and "Noni" juice extract. Songklanakarin J Sci Technol 2005, 27, 579-586.

66. Buschmann, H.; Rodriguez, M.X.; Tohme, J.; Beeching, J.R. Accumulation of Hydroxycoumarins During Post-harvest Deterioration of Tuberous Roots of Cassava ( Manihot esculenta Crantz). Ann. Bot. 2000, 86, 1153-1160, https://doi.org/10.1006/anbo.2000.1285.

67. Alok, N.; Neeraj, K.S.; Neha, J.; Vinod Kumar, D. Analysis of scopoletin and mangiferin in botanicals and formulations of Shankhpushpi by HPLC. Herba Polonica 2018, 64, 54-62, https://doi.org/10.2478/hepo2018-0025.

68. Xia, Y.; Dai, Y.; Wang, Q.; Liang, H. Determination of scopoletin in rat plasma by high performance liquid chromatographic method with UV detection and its application to a pharmacokinetic study. J. Chromatogr. B 2007, 857, 332-336, https://doi.org/10.1016/j.jchromb.2007.07.023.

69. Shinde, P.B.; Katekhaye, S.D.; Mulik, M.B.; Laddha, K.S. Rapid simultaneous determination of marmelosin, umbelliferone and scopoletin from Aegle marmelos fruit by RP-HPLC. J. Food Sci. Technol. 2014, 51, 22512255, https://doi.org/10.1007/s13197-014-1270-5.

70. Kantha Deivi, A.; Jaya Krishna, K.; Shanmugasundaram, H.; Sathesh Kumar, A.; Kamesh Viswanathan, B. HPTLC Finger Print Analysis And Phytochemical Investigation Of Morinda Tinctoria Roxb Leaf Extracts By HPLC and GS MS. International Journal of Pharmacy and Pharmaceutical Sciences 2014, 7.

71. Pachauri, S.D.; Khandelwal, K.; Bhaisora, M.; Pandey, R.R.; Srivastava, A.; Tripathi, P.; Verma, P.R.P.; Dwivedi, A.K. The Preparation of Morinda citrifolia (Noni)-Phospholipid Complex and Its Pharmacokinetics Study in Rats. Journal of Biomaterials and Tissue Engineering 2014, 4, 221-226, https://doi.org/10.1166/jbt.2014.1154.

72. Mahattanadul, S.; Ridtitid, W.; Nima, S.; Phdoongsombut, N.; Ratanasuwon, P.; Kasiwong, S. Effects of Morinda citrifolia aqueous fruit extract and its biomarker scopoletin on reflux esophagitis and gastric ulcer in rats. J. Ethnopharmacol. 2011, 134, 243-250, https://doi.org/10.1016/j.jep.2010.12.004.

73. Vidya, K.S.; Upadhya, R.; Muthusamy, A.; Babu, V.S.; Subramani, J.; Satyamoorthy, K. Cytotoxic efficacy of Noni (Morinda citrifolia L.) fruit extracts and scopoletin on a preponderant panel of human tumor cell lines. Intl Journal of Noni Research 2011.

74. Guetchueng, S.T.; Nahar, L.; Ritchie, K.J.; Daud Ismail, F.M.; Dempster, N.M.; Nnanga, E.N.; Sarker, S.D. Phenolic compounds from the leaves and stem bark of Pseudospondias microcarpa (A. Rich.) Engl. (Anacardiaceae). Biochem. Syst. Ecol. 2020, 91, 104078, https://doi.org/10.1016/j.bse.2020.104078.

75. Thomaz, D.V.; Couto, R.O.; Roberth, A.d.O.; Oliveira, L.A.R.; Leite, K.C.d.S.; Bara, M.T.d.F.; Ghedini, P.C.; Bozinis, M.C.V.; Lobón, G.S.; Gil, E.d.S. Assessment of noni (Morinda citrifolia L.) product authenticity by solid state voltammetry. Int. J. Electrochem. Sci 2018, 13, 8983-8994, https://doi.org/10.20964/2018.09.390.

76. Rohman, A.; Gandjar, I.G. Kimia farmasi analisis. Yogyakarta: Pustaka Pelajar 2007, 298-304.

77. Thuc, D.N.; Thuy, V.T.; Mai, V.T.H.; Thanh, L.N.; Van Quan, V. Chemical constituents from ethyl acetate extract of the stems of Rourea oligophlebia Merr. Vietnam Journal of Chemistry 2020, 58, 298-301, https://doi.org/10.1002/vjch.201900082.

78. Thengyai, S.; Thiantongin, P.; Sontimuang, C.; Ovatlarnporn, C.; Puttarak, P. $\alpha$-Glucosidase and $\alpha$-amylase inhibitory activities of medicinal plants in Thai antidiabetic recipes and bioactive compounds from Vitex glabrata R. Br. stem bark. Journal of Herbal Medicine 2020, 19, 100302, https://doi.org/10.1016/j.hermed.2019.100302.

79. Ines, S.; Ouahiba, B.; Amel, A.; Beretta, G.; Wassila, B.; Meroua Ahmed, C.; Djamila, Z.; Samir, B.; Fadila, B. Antioxidant activity and chemical constituents of Anthriscus vulgaris Bernh. (Apiaceae) from Algeria. Acta Scientifica Naturalis 2020, 7, 59-70, https://doi.org/10.2478/asn-2020-0007.

80. Tabatabaei Mofidi, S.; Moridi Farimani, M.; Nejad-Ebrahimi, S.; Salehi, P. Phytochemical study of Tanacetum sonbolii aerial parts and the antiprotozoal activity of its components. Iranian Journal of Pharmaceutical Research 2020, 19, 77-83, https://doi.org/10.22037/ijpr.2020.1100951.

81. Vipul, U.; Sharma, N.; Tiwari, K.A.; Joshi, H.M.; Malik, A.; Singh, B.; Kalakoti, S.B. Standardization of HPLC Method of Scopoletin in Different Extracts of Convolvulus pluricaulis. International Journal of Pharmaceutical Sciences and Drug Research 2013, 5, 28-31. 